\title{
Walking, Haunting, and Affirmative Aesthetics: The Case of Women without Men
}

\author{
Maud Ceuterick ${ }^{1}$
}

Whether as an everyday social practice or as an artistic or political intervention, walking contributes to the making of space. Spatial content and organisation are made out of and constantly modified by dynamic social relations. For Michel de Certeau, 'the ordinary practitioners of the city live 'down below', below the thresholds at which visibility begins. They walk - an elementary of this experience of the city; they are walkers, Wandersmänner, whose bodies follow the thicks and thins of an urban 'text' they write without being able to read it' $(93,1984)$. Whereas de Certeau writes about walking as an invisible everyday act that may counterbalance overarching power and control, feminist geographers have stressed that practices such as walking are themselves imprinted with power relations (Massey 1994; McDowell 1999; Rose 1993; Spain 1992). If for de Certeau, it is the mundanity of the walkers' practice that provides them with invisibility, this mundanity and the power of being invisible in the urban space are however contingent on more complex social issues, of class, gender, age, ethnicity and sexuality among others. The privilege to inhabit the city 'below the thresholds at which visibility begins' amounts to having a counteracting power that is refused to those who are not included in the term Wandersmänner ('hiking men'). While de Certeau follows Charles Baudelaire's and Walter Benjamin's 'romantic' depictions of the nineteenth century flâneur as an invisible figure of the city, ${ }^{2}$ feminist literature, cinema and digital media have repeatedly denounced the all too visible and dominating presence of white middle class men in urban streets. Through a close analysis of Shirin Neshat's Women without Men (2009), this article explores how haunting the public space empowers Iranian women. As haunting aesthetically opens up places to which women do not normally have access and makes structural inequalities visible, I argue that haunting emerges as a form of 'affirmative aesthetics'. Offering alternatives to the status quo, the film affirmatively shows possibilities that women become 'normal' inhabitants of the public space.

\footnotetext{
${ }^{1}$ Department of Linguistic, Literary and Aesthetic Studies, University of Bergen, Sydnesplassen 7, 5007 Bergen, Norway. This research is funded by a Marie SkłodowskaCurie Fellowship (grant number 800259).

${ }^{2}$ On visibility and invisibility of the flâneur, see Temma Balducci's book Gender, Space, and the Gaze in Post-Haussmann Visual Culture: Beyond the Flâneur (2017).
} 
Numerous fiction films across the history and socio-cultural contexts of cinema portray women protagonists that struggle to inhabit the streets as freely as men do. These include Meshes of the Afternoon (Deren 1943), Wanda (Loden 1970), Messidor (Tanner 1979), The Company of Wolves (Jordan 1984), Vagabond (Varda 1985), The Day I Became a Woman (Makhmalbaf 2000), Far from Heaven (Haynes 2002), Thelma and Louise (Scott 1991), Head-On (Akin 2004), 678 (Diab 2010), Wadjda (Al-Mansour 2012), Girlhood (Sciamma 2014), Wild (Vallée 2014), and American Honey (Arnold 2016). Women have taken digital cameras to document the many obstacles they have to overcome in the streets, such as in "Femmes de la rue" (Peeters 2012), "10 Hours of Walking in NYC as a Woman" (Rob Bliss Creative 2014), and "Creepers on the Bridge" (Van Loon and Ghunim 2014). As these videos point to the unwanted attention given to women in the streets (in these cases, mainly white middle-class women), they also make visible the rape culture, popular misogyny and widespread sexism that permeate society and affect women's freedom of movement as well as that of other oppressed social groups (as widely documented on platforms such as "Everyday Sexism", "Hollaback!" and the Tumblr account "Who Needs Feminism").

In the past decades, women have both taken the digital sphere and the streets to give visibility to the issues that affect their everyday use of urban space. Besides the highly visible marches Slut Walks or Reclaim the Night, other social movements create a tension between the necessity of the campaign visibility and of the (somewhat) invisibility of their partakers. In Iran, the stealthy actions of individual women taking off their hijab and filming themselves have created a collective and internationally visible movement against the compulsory wearing of hijab in public spaces; these have been gathered around the use of hashtags such as \#mystealthyfreedom, \#myforbiddenvoice, \#whitewednesdays, and \#mycameraismyweapon. Iranian cinema has in fact built similar affirmative models of contestation upon making visible those who generally must remain invisible. While this article mainly focuses on the fiction film Women without Men by Iranian filmmaker and artist Shirin Neshat, a number of acclaimed feminist Iranian films portray women that are wilful to step in spaces that are not accommodating to them, such as The Apple (Makhmalbaf 1998), The Day I Became a Woman (Makhmalbaf 2000), The Circle (Panahi 2000), Ten (Kiarostami 2002), Offside (Panahi 2006), Circumstance (Keshavarz 2011), and 3 Faces (Panahi 2018). These films emphasise the wilfulness of Iranian women to fully inhabit public spaces as an affective reaction to "not being accommodated" and being denied what is offered to others (in the words of Sara Ahmed 2014). Rather than an individual reaction, wilfulness is a collective project, one that comes into being both through physical movement and representation. 
While streets and houses have often been considered through binaries, opposing men/women, white/black, public/private, stasis/mobility, city/countryside, bourgeoisie/working class, culture/nature, places are not neutral nor fixed. As human geographers emphasise, place should always be regarded as space-time; in constant transformation through practices and representations, and constituted of "ever-shifting geometry of social/power relations" (Massey 1994, 4). (Certeau 1984; Lefebvre 1974; Massey 1994; McDowell 1999; Rose 1993; Spain 1992; Thrift 2008; Uteng and Cresswell 2008). While "powergeometries" negatively affect the habitation of space of women and other discriminated groups, they also produce collective affects and resistance, which participate in the constant making of space (even if in an invisible fashion as de Certeau argues). Seen in this productive light, I argue that resistance, or rather acts of wilfulness, are to be seen as affirmative.

This article looks at Women without Men as a case study of what I call 'affirmative aesthetics'; a filmic assemblage of forms (constructions of space and bodies) that break with traditional gender norms and the status quo. Through her concept of "Affirmative Ethics", Rosi Braidotti explains that we need to detach ourselves from the incessant quest for meaning, and instead transform negative affects into productive forces (2011a, 292). Following this idea, I look for instances of 'affirmative aesthetics' in film through performing a close textual analysis (a 'microanalysis') of how spaces and bodies visually and aurally interrupt the status quo and create fluid genders, spaces and identities. If the films and digital artworks I mentioned all involve the wilfulness of women protagonists to inhabit space 'freely', wilful affects take shape at both character and aesthetic level, especially through the cinematic construction of space and the characters' micro-relations to space. Following Eugenie Brinkema's work The Forms of the Affects (2014), affects on screen are not expressions of a subject's interiority but rather forces that need to be "read for" in cinematic forms - "shapes, structure, duration, lines, or light" $(2014,23)$. While some examples above such as "Femmes de la rue" or "Everyday Sexism" somewhat overly focus on how the power-geometries of streets and of other so-called 'public' spaces negatively affect women, it is crucial for the affirmative critic to read for - to look for and analyse - forms that wilfully modify the status quo, without which they may remain buried in negative representations of gender expectations and norms.

After several art installations, Shirin Neshat's first film for cinema plays with forms, lights, shapes and textures that interrupt the realism of the narrative, and bring up virtual possibilities into the real. The magic realist character of Women without Men - borrowed from the eponymous novel by Shahrnush Parsipur (1989) from which the film is adapted aesthetically disrupts the patriarchy of space that the diegesis exposes. This article follows three paths that the film takes as it challenges established power-geometries and liberates urban space of gender 
expectations. First, I explore how haunting and (in)visible practices of space challenge gender binaries. Second, as the women protagonists of the film haunt 'public' spaces, they open up what Michel Foucault (1986) calls "heterotopias", a hybrid site in-between the real and the imaginary. Finally, walking gives shape to a political and affirmative statement, which is visible both in the film and across feminist digital media.

The narrative of Women without Men is set in Iran, before and after the British and American 1953 coup d'état that overthrew the democratically elected government of Mohammad Mossadegh. Munis, one of the four main characters, vigorously wants to take part in the demonstrations against foreign control of Iranian affairs and oil. When her brother prohibits her to leave the house, she commits suicide in a poetic and decisive cry for freedom. Once buried, she cries for help to her friend Faezeh, who extracts her from the ground. Without transition between dead and living states, real and unreal, Faezeh and Munis go into the streets to participate in the political upheaval. In the streets, however, Faezeh is attacked and raped, as punishment for her presence into a sphere in which women are not welcome. In order to protect her more fragile and conservative friend from the hostility of the urban space, Munis brings Faezeh to an orchard slightly outside of the city. While Munis, as a ghost, actively takes part in the ongoing political developments, Faezeh experiences a kind of rebirth among the small community living at the orchard: a male gardener, the woman owner Fakhri, and Zarin, an ex-prostitute who has also taken refuge there. At the end of the film, when both the rebellion of the city and the peace of the orchard are defeated, Faezeh walks back towards the city, visibly empowered.

Ghosts have often represented the illegitimate presence of white middle-class women in so-called 'public' spaces, illustrating their removal from places that were not accommodating to them (see Wolff 2006). As Griselda Pollock (1988) has shown, in modern painting of the nineteenth century white middle-class women appeared on balconies or behind windows (what she calls, the 'spaces of femininity') rather than among the crowd dominated by men. ${ }^{3}$ The impossibility of inhabiting public spaces in the same way as men do has transformed the flâneuse into a ghostly figure that persists in artworks nowadays. In Vertigo (Alfred Hitchcock 1958), a dead woman (or her ghost) occupies the mind of the male protagonist, who follows her around throughout the city, keeping her under surveillance, and thus leaving her no legitimacy to fully inhabit the city. Similarly, in Dans la ville de Sylvia (José Luis Guerin 2007) the (male) protagonist chases a woman down the streets of Paris, portraying her in his drawing, while the woman herself (Sylvia, supposedly) remains a mysterious and immaterial escaping creature

\footnotetext{
${ }^{3}$ As Pollock explains, the ideological notion of 'femininity' in modernity separated bourgeois women from working class women and delineated the spaces women had access to depending on their social class $(1988,68-70)$.
} 
without the right to subjectivity, in spite of the title of the film. Haunting, however, may also mean inhabiting, taking space in the streets despite interdictions or limitations to do so such as in Virginia Woolf's essay "Street Haunting: A London Adventure". Similarly, in Women without Men, women haunting the city create visual interruptions of the gendering of space, and give shape to a wilful resistance against sexist spatial boundaries.

Munis' haunting of space starts with her suicide before the credits at the opening of the film. This flash-forward becomes clear when it is evoked again later: Munis is looking for an escape out of the house, which manifests as a prison for her. The film makes visible how the strong division between public and private spaces establishes control over individuals' rights and habitation of space. For Foucault (1975), power builds through the control of space and time, and a continual process of surveillance, sanction, and examination. Although Foucault mainly refers to the disciplinary systems of prisons, schools, factories, and hospitals, these networks of power permeate society as a whole. Originating in patriarchal structures, the striated and gendered division of space threatens women's mobility and access to the public sphere. In Neshat's Iran, imams and the pious community (to which Munis' brother and Fakhri's husband belong) take turns enforcing the Islamic law and surveilling the population, women in particular. Significantly, the chant of an imam resonates as Munis stands on the roof of her house looking down onto the street. ${ }^{4}$ When Munis jumps from the roof, she jumps into complete silence, the imam's chant stops and only her chador falls to the ground while her body flies away. This poetic scene symbolically rejects the Islamic law, as Munis' flying body takes control over her own mobility and ensures her future involvement in the public sphere. The aesthetic of the scene creates an affirmative space inscribed in magical realism, which escapes control and norms in favour of mobile, empowered and politically active citizens.

As Munis' voice-over expresses her desire to find freedom, her face merges into the clouds. The moving clouds in turn dissolve into a river, and the camera continues its uninterrupted forward motion following the river behind a broken wall and into a garden, the orchard that will later welcome the other three women of the film. As the clouds of dawn dissipate, the camera lifts from ground level to the crowns of the trees, recording the chant of birds on its way up, until the title of the film appears on screen. The sunbeams reaching the camera lens in between the trees seems to bring life again to Munis' disembodied voice, as the trees and birdsong merge into Munis' sitting on the living room floor listening to the radio. The voice of the newsreader commenting on the current political situation aurally foregrounds Munis in the political

\footnotetext{
${ }^{4}$ I discuss further the role of roofs, windows and balconies in terms of women's habitation of space in Affirmative Aesthetics and Wilful Women: Gender, Space and Mobility in Contemporary Cinema (Ceuterick 2020).
} 
environment that she wishes to occupy. The low camera's height (at the same height as Munis on the floor) and openness of the frame, filming the sun coming in through the windows and lighting up Munis, creates an affirmative space that she fully inhabits. The emphasis on the diegetic sound coming from the radio brings a part of the street space into the house, interrupting thus the division between private and public space. As we will see, as a ghost of the public space, Munis figures as the spectre of women who could move freely and participate in politics before the coup d'état; she embodies the unerasable history, that which the successive post-coup governments and the later Islamic revolution will attempt to erase and keep under increasing control. In a way, her ghost is the possible future woman of the past, also embodied by the orchard itself and its mysterious gardener, both of whom have lived through different political times. Intermingling temporal realities and magical elements, the film queers present Iranian politics and creates an affirmative horizon of potentialities. In his book Cruising Utopia: The Then and There of Queer Futurity, José Esteban Muñoz defines queerness as "an ideality that can be distilled from the past and used to imagine a future" $(2009,1)$. For Muñoz, utopia allows us "to see beyond ... 'what is' to worlds of political possibility, of "what might be'”(2009, 38). Similarly, I describe affirmative artworks as creating forms that bring alternative possibilities into present narratives, or in other words, that queer the present and its enduring status quo.

Throughout the film, 'micro-instances of affirmation' give shape to the cinematic space, and evoke the constant transformation of powergeometries and possible de-gendering of space. As the film articulates a critique of the limitations on women to become mobile and participate in the forming of public opinion, resistance takes affirmative shapes on screen. Writing that "the material that damages is also that which engenders positive resistance, counteraction, or transcendence" (Braidotti 2011a, 285), Braidotti explains that "affirmation is about freedom from the burden of negativity, through the understanding of [our multiple] limitations" (2011b, 269). The film places emphasis on the wilfulness Munis experiences as her brother forbids her to go into the street and participate in the uprising against the coup d'état. This wilfulness manifests as a refusal to be erased, to be rendered silent and invisible. If at the beginning of Women without Men, cafés and streets appear as male dominated environments, unsuitable for women, after her suicide, Munis becomes both visually and aurally an active participant in the public sphere.

After her friend Faezeh digs her out of the ground, Munis goes straight to a café where she listens to the news. Faezeh follows her to the café, but stays outside, being aware of the restrictions for women to come into cafés. Whereas the wilful figure of Munis appears unobscured in the foreground of the image as she is listening to the radio, the small figure of her friend remains in the background of the image entrapped by 
multiple frames (see Figure 1). In addition to the framing of the scene, the balanced lighting situates Munis in an environment that she is appropriating, while very bright lighting (also due to the high contrast between interiors and exteriors) washes the background of the image and almost erase Faezeh from the street where she stands. Likewise, the following scene portrays Faezeh crawled up on the porch of a house after she has been assaulted by two men from the café who chased her down the street as she was walking away. The cinematic space again encloses Faezeh, as a bodyless black shape under her chador that is belittled by the standing black shape of Munis and by door frames and walls surrounding her on all sides. Although being the one who is dead, Munis' embodied appearance on screen contrasts with the retreated appearances of Faezeh and Zarin, who seem to visually excuse themselves for their own physical presence. Munis often appears well lit and taking space on screen, as opposed to Faezeh and Zarin, whose characters are enclosed between lines, shades, and among objects, to the point of almost disappearing. Munis', Faezeh's and Zarin's haunting of public places problematises and counteracts Habermas' idea that mobility is a "democratic right", and the public sphere, "a sphere of personal freedom, leisure, and freedom of movement" (cited in Sheller and Urry 2000, 741).

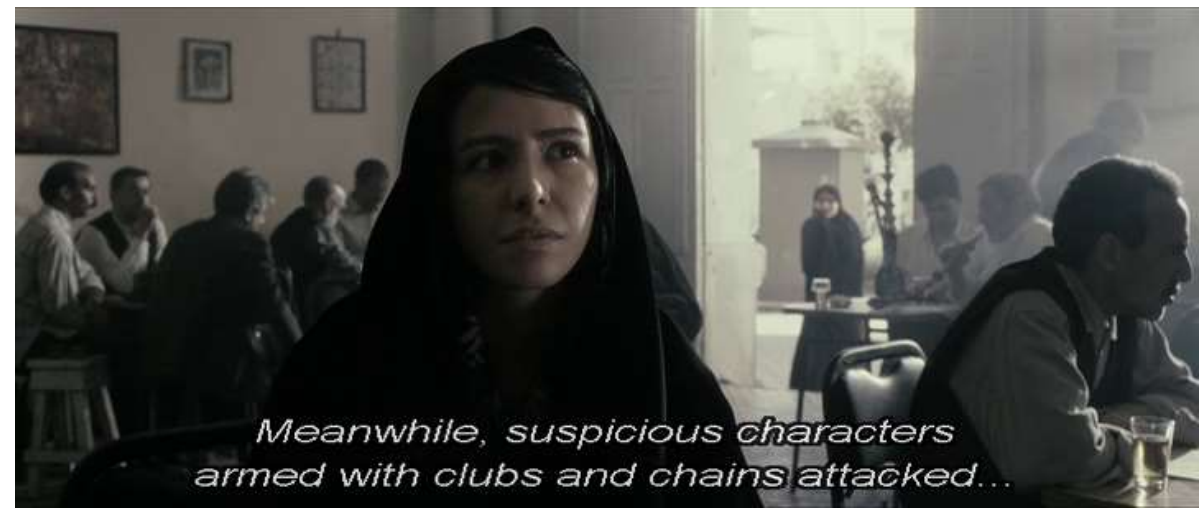

Figure 1: Women without Men: Munis listening to the radio in a café while Faezeh remains outside | @ Essential Filmproduktion/coop99 filmproduktion/Parisienne de Production

A micro-analysis of space and affects as forms brings to the fore the virtual within the real, that is the continuous changes, the process of becoming that spaces undergo through time and the actions of bodies. Neshat's film echoes Jacques Derrida's perception of spectres, for whom the binaries of life and death, real and unreal, figure as false oppositions that collapse with each attempt to solidify and fix them (as explained by Valverde 1995, 336). In the Specters of Marx, Derrida refers for example to the ghost of Hamlet as a powerful figure able to "set a major chain of historical events in motion" (Valverde 1995, 334). Similarly, Munis' ghost takes an active part in the rebellion against the 1953 coup. As a 
member of the rebellion approaches her in the café where she listens to the radio and introduces her to the organised underground movement, the silhouette of her face in the foreground 'eats' the light from the image and places her in a leading position (see Figure 2). As a ghost, Munis in fact becomes highly visible as she penetrates the roaring crowd: she interrupts a monochromatic medium shot of men all dressed in white, and thereby disturbs the homogeneity of the city streets. Her wilful figure absorbing the light of the scenes creates an interstice in the image, and visually makes space to alternatives to the gendered urban space.
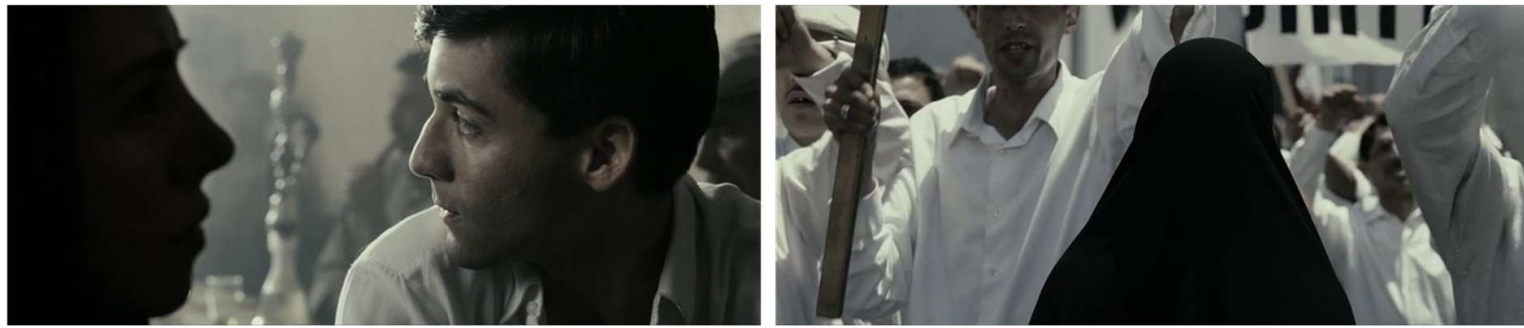

Figure 2: Women without Men: Munis' body cuts into the image | (c) Essential Filmproduktion/coop99 filmproduktion/Parisienne de Production

Through magical realism, the affirmative aesthetics of Women without Men brings light and gives a voice to both the past and possible futures, actualising the desires of women to be mobile and involved in the public sphere. Munis' haunting presence in the frame brings changes to the soundtrack, silencing the uproar of the streets or adding music to it. As these sound variations manifest as subtle changes between real and unreal, realistic and magical spaces, they reinforce the continuum between life and death, virtual and actual (in Deleuzian terms). ${ }^{5}$ Munis' monotone and poetic voice-over reflects on her own political role, as it continually interrupts the diegetic and simultaneous sound of the chanting crowd. As her voice silences the crowd, it aesthetically 'makes space' for women's voices to be heard, thereby affirmatively producing a political space that is inclusive of women. On the one hand, Munis has formally become a ghost: she looks at people who do not look back at her, and her voice-over talks to people (the spectators) who do not talk back. Her aesthetic representation as ghost symbolises women's limited access to public space and depicts how they need to work in the interstices of the city, while also critiquing how canonic history and literature has often overlooked the role of women revolutionaries. On the other hand, Munis' bodily presence on screen, impact on sound and the image, and Neshat's insistent filming of women leading or among the

\footnotetext{
${ }^{5}$ For Deleuze, the virtual is always present within the real, the real containing objects that are actualised or in a virtual state. Describing the relations between the actual and the virtual, Elizabeth Grosz writes that "each object is more than itself [and] contains within itself the material potential to be otherwise" (Grosz 2005, 10).
} 
crowd, bring the freer women of Iran back to life, evoking thus an era prior to the 1953 coup and 1979 Islamic revolution, and cinematically producing alternative futures. Both aesthetically and symbolically, haunting emerges as an instance of affirmative aesthetics that brings the virtual into the real and transforms negative affects into productive forces. Haunting materialises a critique that revives and gives space to those who have been silenced, unseen or hidden from history.

A close reading of how the film introduces magical elements within the real, and of how forms, textures, lights, sound and rhythm construct the cinematic space reveals both characters' subjectivities and alternative possibilities to the status quo. For instance, when Fakhri meets her (inferred) ex-lover in a restaurant and tells him that she is leaving her husband (an official in the military) and buying a house in an orchard for herself, she is shown in a multiplicity of mirrors while climbing the stairs of the restaurant (see Figure 3 ). This scene reminisces other famous similar scenes in the history of cinema, in films including Citizen Kane (Welles 1941) and Cléo de 5 à 7 (Varda 1962). This spatial representation gives shape to the in-betweenness of her situation, being an independent woman and the wife of a respected general. It also depicts her vanity in pleasing men (which the film's ending condemns) and her entrapment in this gender role, which was also at the core of Cléo de 5 à 7 and, in a different fashion, of Citizen Kane. This entrapment also takes form with the sound of her heels on the tiled floor, which pierces through the silence. The diverging gazes of her multiplied bodies looking in a multitude of directions indicate the possibilities she has to escape her clustered habitation of space and build a space for herself, which is reinforced by the mise-en-scène of this restaurant scene, and the montage with the previous and following scenes. Bird sounds, large windows and wide establishing shots aesthetically open up the otherwise confined framing of Fakhri with her husband that gives shape to their relationship. Looking at these scenes through a phenomenological and geographical lens reveals affirmative forces, paths of escape from established (and gendered) models of subject and spaces.

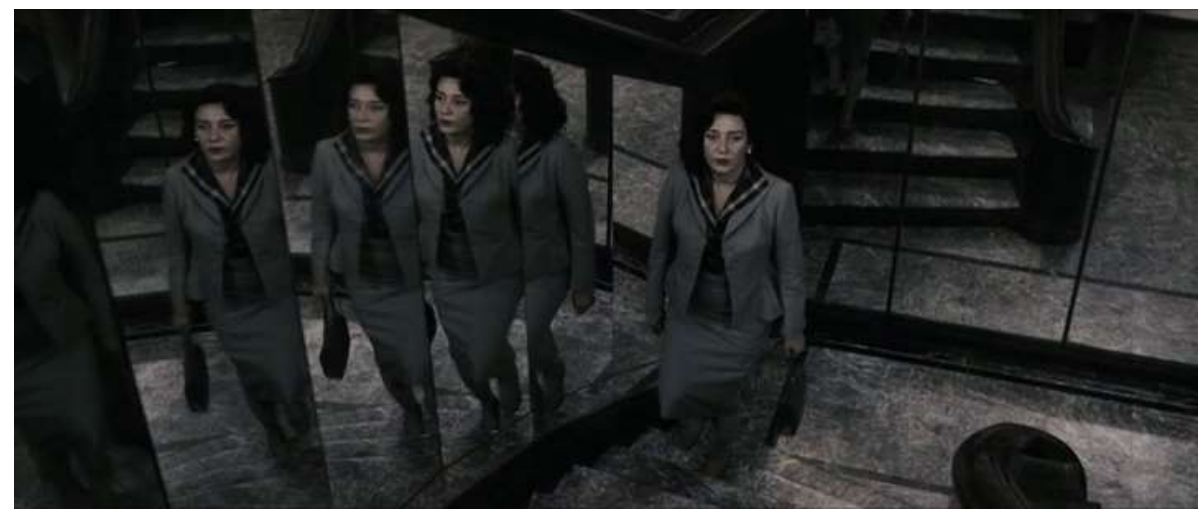

Figure 3: Women without Men: Fakhri’s reflection in a multiplicity of mirrors | (c) Essential 
The orchard materialises as a hybrid space between real and unreal that encapsulates the magical realism of the film. From the start, the orchard's marked variations between abundant and scarce vegetation, striated dark interiors and unobstructed bright exteriors visually depict it as between life and death, both causing death and bringing back to life. The magical realist aesthetic creates what Homi Bhabha has termed a "third space', which enables other positions to emerge" (qtd. in McDowell 1999, 213). When Fakhri visits the orchard for the first time, she finds the leftovers of a meal laying on the dinner table as if the past inhabitants left in a hurry, or never left, but disappeared. A mysterious nameless gardener welcomes her in the domain, and elusively admits that he has been living there "as long as [he] can remember". His character and the orchard open up a third space, where gender norms can be challenged.

In the orchard, and around the gardener, allusions to haunting multiply. When Fakhri moves in her new house, she finds the inanimate body of Zarin floating in a pond of the orchard, lying just as Hamlet's Ophelia as depicted by John Everett Millais (1852). Zarin's character epitomises the linearity between life and death, real and unreal. The magical realism of Zarin's narrative starts with her encounter with the gardener as a client of the brothel where she works, when his mouth and eyes dissolve from his face while he sits on her bed and strokes her shoulder, embodying both a potential lover and a comforting father. Neshat's film establishes numerous parallels between Zarin's story and Shakespeare's play, among which the sexist questioning of women's sexuality, and Zarin's loss of her girlhood to prostitution, which somewhat echoes Ophelia's loss of her father at the hands of a lover accusing her of immodesty. ${ }^{6}$ Zarin simultaneously manifests as a wilful woman, escaping the brothel and asserting her autonomous self, and fits Marnina Gonick's critique of psychologist Mary Pipher's Ophelia as "vulnerable, voiceless and fragile" (Gonick 2006, 2). Gonick describes the 1990s seemingly opposite depictions of femininity 'Girl Power' and 'Reviving Ophelia' (the title of Pipher's book) as interrelated neoliberal projects of female subjects that relie on an self-empowered yet vulnerable individual rather than on social collectivity $(2006,18)$. Zarin's well-being in the film seems to act as a barometer of Iranian society and collective welfare against the UK and US neoliberal imperialism imposed on Iran through through the 1953 coup. The film's portrayal of Zarin and of the orchard as alternatively lively or lifeless reflects the political and social anxieties going on in Iran at the time and the subsequent failure of collective organisation against the overthrow of the democratically

\footnotetext{
${ }^{6}$ The figure of Ophelia has also served the analyses of girlhood in Sophia Coppola's The Virgin Suicides (1999) by Fiona Handyside (2017) and Anna Backman Rogers (2018).
} 
elected government.

Visually and aurally, the orchard reflects the constant alteration of power-geometries in the city streets and in Iran more broadly. As the women of the film inhabit the diegetic spaces (the house and the city streets) more fully, the vegetation of the orchard becomes increasingly lush. In this way, the orchard offers a heterotopian site, measuring the queering of the status quo, the utopia enacted by Munis' visible involvement in the public sphere, filmed in open bright shots (see Figure 4). In Foucault's words, heterotopias manifest as

real places - places that do exist and that are formed in the very founding of society - which are something like counter-sites, a kind of effectively enacted utopia in which the real sites, all the other real sites that can be found within the culture, are simultaneously represented, contested, and inverted. (Foucault 1986, 24).

In this sense, the orchard illustrates how gender, social, and historico-political issues constantly transform space. In-between urban streets and domestic space, it offers a heterotopia, a 'counter-site' to resist the gendering of space and patriarchal control. Both secluded from the city and partially open to it - which is symbolically depicted by Munis' and Zarin's entrance through a hole in the wall that surrounds the garden -, the film alternately portrays the orchard as a utopian haven of peace or as striated and dangerous. Similarly, magical realism affects the orchard's cartography, at times enclosed behind a big wall with only a small hole and a heavy metal door as possible entrances, or as a wild (at times tropical) forest that is open onto the neighbouring deserted planes. The haunted orchard figures as a heterotopia, "an unreal, virtual space that opens up behind the surface" in Foucault's words $(1986,24)$. While both the streets and the orchard merge real and unreal, virtual and real, the orchard also allows women to have a room of their own, and "to see [themselves] there where [they are] absent" (Foucault 1986, 24), reviving Iranian pre-coup's society and opening up possible futures in the time of the film, post 2000 s. 


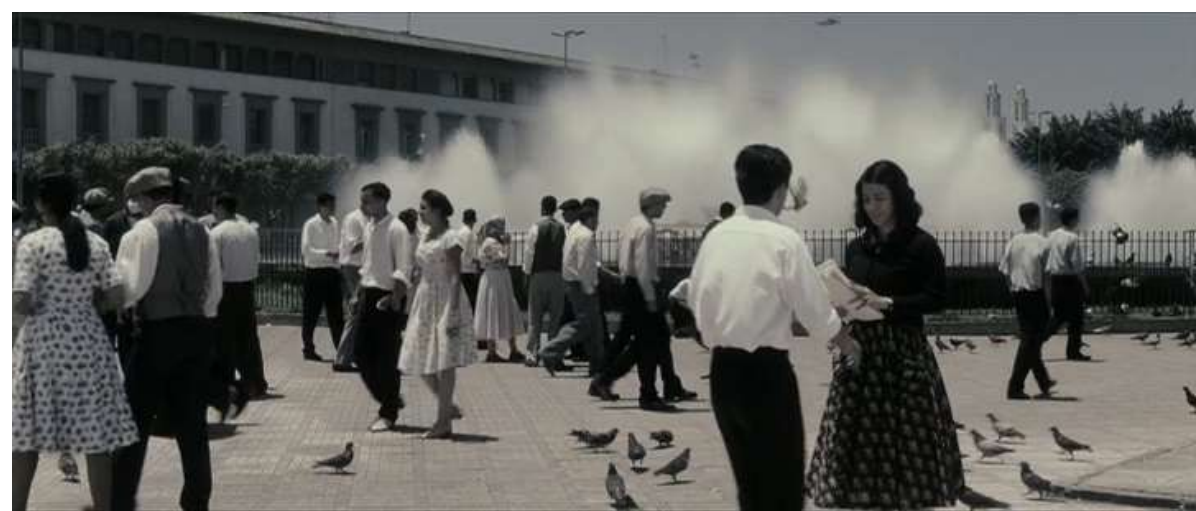

Figure 4: Women without Men: Munis participates in the public sphere | (C) Essential Filmproduktion/coop99 filmproduktion/Parisienne de Production

Faezeh's micro-relations to space in the city and in the orchard are perhaps the most representative of women's problematic habitation of space. The patriarchal control over women's movement and sexuality, "between public space and private parts", as Rebecca Solnit cleverly puts it, determines women's access to social, cultural and political spaces, "limited for women by their fear of violence and harassment,...[f]ear of rape [putting] many women in their place - indoors, intimidated, dependent yet again on material barriers and protectors rather than their own will to safeguard their sexuality" (2001, 240). While this sentence places the burden of "safeguarding their sexuality" on individual women instead of rightfully addressing the problems caused by systemic patriarchal structures, it also highlights how affects such as fear produced by the violence and harassment inherent to institutional sexism - preserve the division of space and the confinement of women behind doors, walls and in Women without Men, symbolic walls such as the chador. The many walls in the film, aesthetically enclosing the four women of the film in established gender roles - of Munis' house and around her garden, dividing the brothel and the hammam into small rooms for Zarin, confining Fakhri with her husband, and enclosing Faezeh in narrow streets and in the orchard -, are all walls that collapse during the film. As they collapse narratively under the wilfulness of the protagonists to escape their oppressive situations, they manifest aesthetically through the changes of the orchard's vegetation and of symbolic walls such as the women's chadors. Chadors confine them in a fixed idea of gender and femininity and figure as self- and socially imposed walls. In the film, the chador gives form to the gendering of space, and embodies both patriarchal control and the fear of it (and of the consequences of not abiding by its laws). For Faezeh, this wall falls as she experiences the wilfulness to assert her own body presence and fully inhabit space.

Due perhaps to her long expatriated life in the West, Neshat's position towards the veil may seem unsubtle. If the veil could also be a 
matter of religion or social class, in the film, it appears to function as an unambiguous indicator of women's freedom, restricted mobility and limited involvement in the public sphere; physically limiting their ability to move instead of protecting them from the assault or harassment they fear (Mahdi 2002, 201). Whereas the chador could function as a disguise, a screen that confers women the invisibility they need to venture into 'public spaces, which are, by definition, male spaces' (Mernissi 1975, 81), the chador in Neshat's film only seems to signify women's loss of their bodily presence while wearing it and bears the negative affect of not being accommodated. As mentioned earlier, Faezeh's chador failed to protect her against rape, but only appeared as diminishing her wilful attitude, reducing her presence on screen to a small bodiless form among objects bigger than herself.

When Faezeh arrives at the orchard after being assaulted in the streets of Teheran, the camera films her reflection in the mirror through the partial opening of her room door, a scene in which she appears as a black shape enclosed in multiple frames while praying. This mise-enscène again emphasises her inadequate presence in social spaces. When she notices the presence of the (male) gardener outside her window, Faezeh hastily locks herself in total darkness, and only leaves as source of light on screen a few faint lines coming through the shutters of the window. While the chador and the window shutters work as selfimposed barriers for Faezeh to "safeguard her sexuality", the faint lines of light and Munis' whispering voice starting to resonate in the darkness manifest as "cracks in the mirror" of Faezeh's reality, which until then seemed to be determined by strict unescapable gender norms. Magically drawn into the darkness of the woods, following Munis' voice, Faezeh dreams of the assault and becomes (again) an unwelcomed inhabitant of space. There, she takes off her chador as if to move in Munis' direction more easily, and never puts it back on in the remaining of the film. An infinite series of dark trees produces shades on her face and white summer dress - which stands out in the deep blue night -, while whispering voices and sombre bell notes create a nightmarish atmosphere. Whereas the setting of the scene gives form to the fear induced by patriarchal spaces, haunting occurrences produce an opening into the virtual of the reality presented on screen. Munis' whisper and fleeting chador generate short hopeful instances that Faezeh attempts to grasp and follow, although these images also evoke how Munis abandoned her in the streets of Teheran, which leads Faezeh to relive the two men's assault upon her.

The continuity editing between Faezeh's room and the forest in this sequence, produced by Munis' voice and the intense darkness, provides an aural and visual transition to a magical, virtual space, an alternative to the gendered real. In a symbolic way, Faezeh is reaching behind the mirror that was enclosing her earlier, just as Alice in Lewis 
Carroll's Through the Looking-Glass (1871), the mirror in fact functioning as a heterotopia 'enabling her to see herself where she is absent' (following Foucault). Faezeh is travelling to an alternative reality that already existed within the real. It is the passage from a space of negative affects to a utopian one that gives shape to the affirmative aesthetics, the formal construction of two different time-spaces that exist in conjunction, as alternatives. Immediately after her witnessing of her own assault, a forward tracking camera approaches Faezeh, now sat on the ground with her back facing the camera. The movement from a slightly high angle indicates a presence that could be standing over her, and causes her to turn around. The presence, however, is not a scary one, but a wilful one, similar to Munis'. As Faezeh turns around and gets up, she sees Zarin, whose ghostly and artificially lit body, wearing a luminous white dress, magically appeared behind her. As she follows Zarin's white illuminated body walking slowly in between the trees (as opposed to the eerie running Munis making brief appearances hidden by her chador earlier), Faezeh seems to go deeper in the reality that exists behind the mirror. A faint sound of rustling leaves and a soft violin melody have replaced the sombre chime and the worrying whisper of Munis.

If Munis' presence in the city aesthetically disrupts the established power-geometries of urban space, her uncanny and dark appearances in the forest bring to mind how outdoor and social spaces do not easily and fully accommodate women. The oppositely colour-coded and fully embodied haunting of Zarin places the real and the virtual on the same plane. Zarin's appearance is a product of magical realism rather than of Faezeh's dream, as Zarin unexpectedly comes back to life the next morning after a long sleep. In parallel with Zarin's awakening, Faezeh wakes up from her disturbing dream, and walks in an unobscured closeup out of the forest and towards the open desert. Contrasting with the desolate arid forest that Faezeh crosses when she arrives at the orchard after the assault, she now finds Zarin sitting in her luminous white dress amidst a miraculously revived bed of colourful flowers (see Figure 5). The light sounds of her steps, the chanting birds, and the slow piano melody in major tone create a joyful scene. While non-diegetic music contributes to the narrative by indicating changes of mood, it also creates space in film. The successive visual and aural changes in the nightmare sequence and the following sequence the next morning can be read as an experience of wilfulness. Unobstructed wide images have replaced the lines and shades enclosing Faezeh, and aesthetically manifest the conversion of negative affects - resulting from women's oppression into productive forces that may generate alternative futures. 

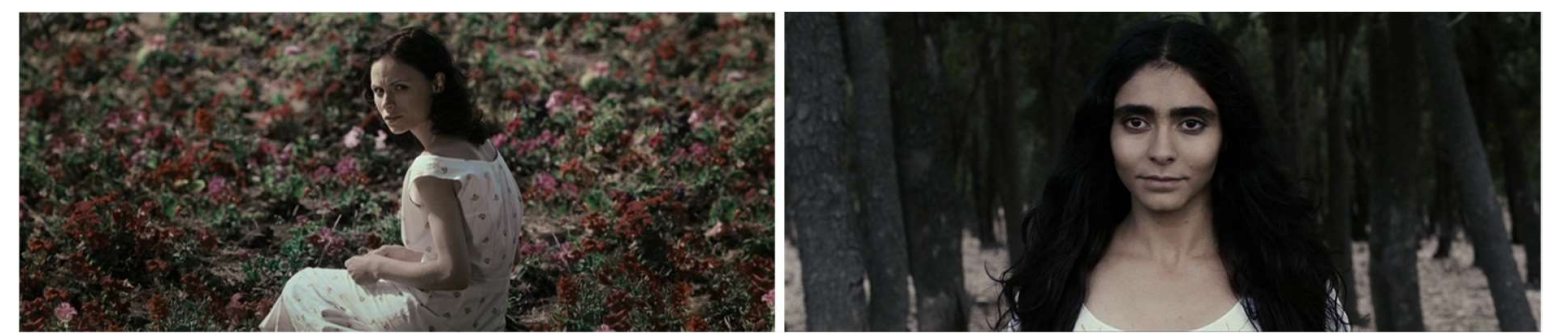

Figure 5: Women without Men: Faezeh looks at Zarin surrounded with flowers | (c) Essential Filmproduktion/coop99 filmproduktion/Parisienne de Production

When Faezeh leaves the orchard at the end of the film and returns to the city, she walks unveiled towards the fixed camera. On the one hand, her characterisation as an individual self-empowered woman may appear as a neoliberal Girl Power figure, one that succeeds where Zarin as Ophelia has failed (as Zarin dies when the organised rebellion collapses and the orchard loses its heterotopian status). On the other hand, this seemingly individual achievement could not have happened without the engagement of a whole community; a collectivity of women who lived together in the orchard and a political collectivity that rose against foreign economic control and Islamic laws. Simultaneously to this ending scene, Munis terminates her fall from the roof, which she had started with the opening credits. As her body falls to the ground in a poetic slow motion, her voice-over explains that "death is not that hard" and that the rebellion movement was looking for "a new way", one that is brought about by collective social movements, which the dedication at the end of the film confirms, to the ones who fought for "freedom and democracy in Iran - from the Constitutional Revolution of 1906 to the Green Movement of 2009”.

If Munis' fall and the diegetic failure to prevent the coup d'état seem to express defeat, the aesthetic of the two final parallel scenes is affirmative of resistance to the status quo. The long take and broad open shot of Faezeh walking decidedly unveiled towards the camera (and the city) evokes the continuity of resistance and the constant transformation of space. This scene highly contrasts with the earlier scene of Faezeh following Munis to the orchard at the beginning of the film, both fully covered by their chador and walking - almost running - away from the camera and the city (see Figure 6). The sound of Faezeh's fast steps now wilfully break the silence, creating a sustained rhythm, the rhythm with which her bodily habitation of space comes in the way of patriarchy. These aesthetic choices give form to wilful affects, the wilfulness of interrupting the patriarchal domination of public spaces. Similarly, Munis' fall in slow motion produces affirmative affects: as she faces the camera, with a peaceful expression and eyes open, and then lies on the ground in the middle of the street with her arms open symmetrically by her side, she occupies space that was denied to her by physically putting her body in the way. Through Munis' haunting and taking place, the 
street itself becomes a heterotopia, a site for politics, at once a real place regulated by laws and socio-cultural norms, and an "enacted utopia" (in Foucault's terms). The merging of real and unreal, magical and realistic elements is a reclaiming of the street space, the filmic actualisation of possibilities that are always present within the real albeit often made invisible. Both aesthetically and narratively, Munis' and Faezeh's walking in or towards the urban space give shape to spatial claim and political rebellion.
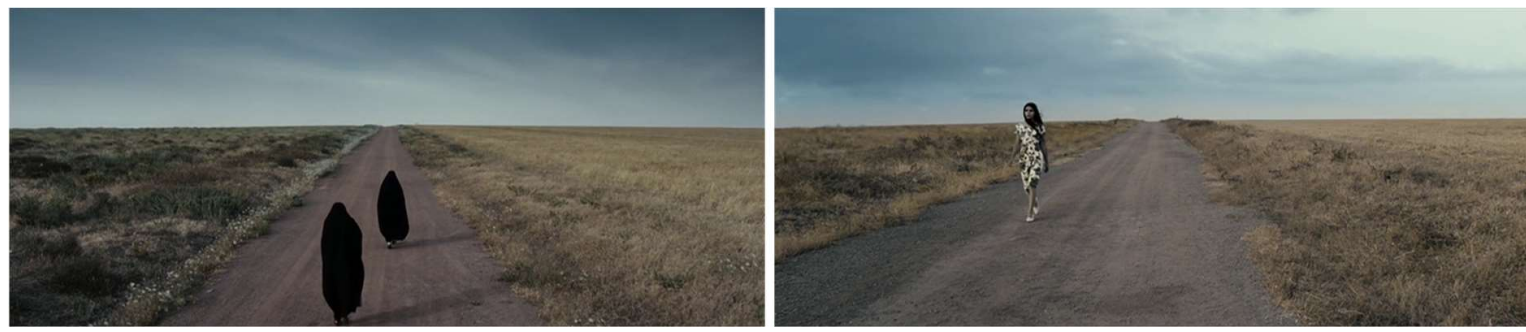

Figure 6: Women without Men: Munis leading Faezeh to the orchard, and Faezeh coming back to the city | (c) Essential Filmproduktion/coop99 filmproduktion/Parisienne de Production

Through a narrative of haunting, and an affirmative aesthetics that makes space for oppressed bodies, Women without Men exemplifies the problems of unequal power-geometries between men and women, and the power of collectivity. As the women furtively appearing without a veil in the social movements \#mystealthyfreedom, \#whitewednesdays, and \#mycameraismyweapon, the protagonists of Women without Men become political haunters, countering the sexist precepts that have maintained them as ghosts of the city, meant to be kept quiet and invisible. The digital accumulation of individual instances of rebellion highlights how walking and the wilful habitation of space can become styles of politics. As a micro-resistance to the gendering of space, haunting reveals that social relations continually transform both urban and domestic space, which exist on a continuum between dead and alive, real and unreal. Haunting becomes an aesthetic, narrative, and political practice that needs to be read for, both looked for and interpreted. This article has shown how critical work may uncover micro-reconfigurations of space. As they open up space for wilful bodies, social media activism and films such as Women without Men generate affirmative aesthetics that counteract current power-geometries, and open up alternatives to the status quo.

\section{REFERENCES}

Ahmed, Sara. 2014. Willful Subjects. Durham: Duke University Press. 
Rogers, Anna Backman. 2018. Sofia Coppola: The Politics of Visual Pleasure. New York: Berghahn Books.

Balducci, Temma. 2017. Gender, Space, and the Gaze in Post-Haussmann Visual Culture: Beyond the Flâneur. New York: Routledge.

Braidotti, Rosi. 2011a. Nomadic Theory: The Portable Rosi Braidotti. Chichester, NY: Columbia University Press.

- - . 2011b. "The New Activism: A Plea for Affirmative Ethics." In Art and Activism in the Age of Globalization, edited by L. De Cauter, R. De Roo, and K. Vanhaesebrouk, 264-70. Rotterdam: NAi Publishers.

Brinkema, Eugenie. 2014. The Forms of the Affects. Durham/London: Duke University Press.

Ceuterick, Maud. 2020. Affirmative Aesthetics and Wilful Women: Gender, Space and Mobility in Contemporary Cinema. Hampshire: Palgrave Macmillan.

de Certeau, Michel. 1984. The Practice of Everyday Life. Berkeley: University of California Press.

Foucault, Michel. 1975. Surveiller et Punir: Naissance de La Prison. Paris: Gallimard.

——_. 1986. "Of Other Spaces.” Diacritics 16 (1): 22-27.

Gonick, Marnina. 2006. "Between" Girl Power" and" Reviving Ophelia": Constituting the Neoliberal Girl Subject." NWSA Journal 18 (2): $1-23$.

Grosz, Elizabeth. 2005. "Bergson, Deleuze and the Becoming of Unbecoming." Parallax 11 (2): 4-13.

Habermas, Jürgen. n.d. The Structural Transformation of the Public Sphere: An Inquiry into a Category of Bourgeois Society. Malden: Polity Press.

Handyside, Fiona. 2017. Sofia Coppola: A Cinema of Girlhood. London/New York: Bloomsbury Publishing.

Lefebvre, Henri. 1974. La Production de L'espace. Paris: Anthropos.

Mahdi, Ali Akbar. 2002. "Perception of Gender Roles Among Female Iranian Immigrants in the United States." In Women, Religion and Culture in Iran, edited by Sarah F. D. Ansari and Vanessa Martin, 189-214. Richmond, Surrey: Curzon in association with the Royal Asiatic Society of Great Britain; Ireland.

Massey, Doreen. 1994. Space, Place, and Gender. Minneapolis, MN: University of Minnesota Press.

McDowell, Linda. 1999. Gender, Identity and Place: Understanding Feminist Geographies. Minneapolis: University of Minnesota Press. 
Mernissi, Fatima. 1975. Beyond the Veil: Male-Female Dynamics in a Modern Muslim Society. Cambridge: Schenkman.

Muñoz, José Esteban. 2009. Cruising Utopia: The Then and There of Queer Futurity. New York: New York University Press.

Parsipur, Shahrnush. n.d. Women Without Men: A Novel of Modern Iran [Zanān Bidūn-I Mardan]. New York: Feminist Press.

Pollock, Griselda. 1988. Vision and Difference: Femininity, Feminism, and Histories of Art. London/New York: Routledge.

Rose, Gillian 1993. Feminism and Geography: The Limits of Geographical Knowledge. Cambridge: Polity Press.

Sheller, Mimi, and John Urry. 2000. "The City and the Car." International Journal of Urban and Regional Research 24 (4): 737-57.

Solnit, Rebecca. 2001. Wanderlust: A History of Walking. London: Penguin Books.

Spain, Daphne. 1992. Gendered Spaces. Chapel Hill: University of North Carolina Press.

Thrift, Nigel John. 2008. Non-Representational Theory: Space, Politics, Affect. New York: Routledge.

Uteng, Tanu Priya, and Tim Cresswell. 2008. Gendered Mobilities. Farnham: Ashgate Publishing Ltd.

Valverde, Mariana. 1995. "Review: Deconstructive Marxism.” Labour / Le Travail 36: 329-40.

Wolff, Janet. 2006. "Gender and the Haunting of the Cities (or, the Retirement of the Flâneur)." In The Invisible Flâneuse?: Gender, Public Space, and Visual Culture in Nineteenth-Century Paris, edited by Aruna D'Souza and Tom McDonough, 18-31. Manchester: Manchester University Press.

\section{FILMOGRAPHY}

3 Faces/Se Rockh [feature, DVD] Dir. Jafar Panahi, Jafar Panahi Film Productions. Iran, 2018.

"10 Hours of Walking in NYC as a Woman" [Video Online] Prod. Rob Bliss Creative - A Viral Video Agency, YouTube. New York, USA, 2014.

678 [feature, DVD] Dir. Mohamed Diab, Audio Visual Entertainment. Egypt, 2010.

American Honey [feature, DVD]. Dir. Arnold, Andrea, Film4. UK/ USA, 2016.

The Apple [Sib] [feature, DVD] Dir. Samira Makhmalbaf, Artificial Eye. 
Iran, 1998.

The Circle [Dayereh] [feature, DVD] Dir. Jafar Panahi, Winstar TV. Iran, 2000.

Circumstance [feature, DVD] Dir. Maryam Keshavarz, Lionsgate. Iran, 2011.

Citizen Kane [feature, DVD] Dir. Welles, Orson, RKO Radio Pictures. USA, 1941.

Cleo from 5 to $7 /$ Cléo de 5 à 7 [feature, DVD] Dir. Agnès Varda, Ciné Tamaris. France/ Italy, 1962.

The Company of Wolves [feature, DVD] Dir. Neil Jordan, Hen's Tooth Video. United Kingdom, 1984.

"Creepers on the Bridge" [Video Online] Dir. Tinne Van Loon and Colette Ghunim, Vimeo. Cairo, Egypt, 2014.

The Day I Became a Woman [Roozi Ke Zan Shodam] [feature, DVD] Dir. Marzieh Makhmalbaf, Makhmalbaf Productions. Iran, 2000.

Far from Heaven [feature, DVD] Dir. Todd Haynes, Focus Features; Vulcan Productions. USA/France, 2002.

"Femmes de la rue" [Video Online] Dir. Sofie Peeters, Sponsume. Belgium, 2012.

Girlhood [feature, DVD] Dir. Céline Sciamma, Hold Up Films. France, 2014.

Head-on/Gegen Die Wand [feature, DVD]. Dir. Fatih Akin, Strand Releasing. Germany/Turkey, 2004.

In the City of Sylvia/Dans la ville de Sylvia [feature, DVD] Dir. José Luis Guerın, Axiom Films. Spain/France, 2007.

Meshes of the Afternoon [feature, Video]. Dir. Deren, Maya, Wellspring Media. USA, 1943.

Messidor [feature, VHS] Dir. Alain Tanner, Citel Films. Switzerland, 1979.

Offside [feature, DVD] Dir. Jafar Panahi, Artificial Eye. Iran, 2006.

Ten [feature, DVD] Dir. Abbas Kiarostami, MK2 Productions. France/ Iran, 2002.

Thelma and Louise [feature, DVD] Dir. Ridley Scott, MGM Home Entertainment. USA, 1991.

Vagabond [Sans Toit Ni Loi] [feature, VHS] Dir. Agnès Varda, Ciné Tamaris. France, 1985.

Vertigo [feature, DVD] Dir. Alfred Hitchcock, Alfred J. Hitchcock Productions. USA, 1958. 
WALKING, HAUNTING, AND AFFIRMATIVE AESTHETICS | 115

Wadjda [feature, DVD]. Dir. Haifaa Al-Mansour, Sony Pictures Home Entertainment. Saudi Arabia/ Germany, 2012.

Wanda [feature, DVD] Dir. Barbara Loden, Parlour Pictures. USA, 1970.

Wild [feature, DVD] Dir. Jean-Marc Vallée, Fox Searchlight Pictures. USA, 2014.

Women Without Men/Zanan-E Bedun-E Mardan [feature, DVD] Dir. Shirin Neshat, Essential Filmproduktion. Iran, 2009.

Submitted in 15-06-2019. Accepted for publication in 26-12-2019. 